\title{
Propolis Supplementation on Broiler Chicken Performances, Nutrient Digestibility, and Carcass Characteristics: A Meta-Analysis
}

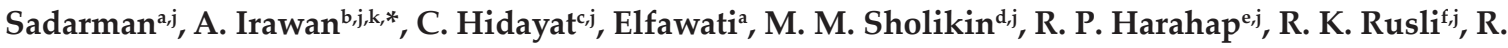 \\ Solfaines, A. Sofyan ${ }^{\mathrm{h}, \mathrm{j}}$, Nahrowi $\mathrm{i}^{\mathrm{i}, \mathrm{j}}$, \& A. Jayanegara ${ }^{\mathrm{i}, \mathrm{j}}$ \\ aDepartment of Animal Science, Sultan Syarif Kasim State Islamic University, Pekanbaru, Indonesia \\ bVocational School, Universitas Sebelas Maret, Surakarta 57126, Indonesia \\ cIndonesian Research Institute for Animal Production, Ciawi Bogor 16720, Indonesia \\ ${ }^{\mathrm{d}}$ Graduate School of Nutrition and Feed Science, Faculty of Animal Science, IPB University, \\ eAnimal Science Study Program, Faculty of Agriculture, Tanjungpura University, Pontianak 78124, Indonesia \\ fDepartment of Animal Nutrition and Feed Technology, Faculty of Animal Science, Andalas University, \\ Padang, Indonesia \\ gDepartment of Pathology, Faculty of Veterinary Medicine, Universitas Wijaya Kusuma, Surabaya 60225, Indonesia \\ hResearch Division for Natural Product Technology (BPTBA), Indonesian Institute of Sciences (LIPI), \\ Yogyakarta 55861, Indonesia \\ iDepartment of Nutrition and Feed Technology, Faculty of Animal Science, IPB University, \\ jAnimal Feed and Nutrition Modelling Research Group, Department of Nutrition and Feed Technology, \\ Faculty of Animal Science, IPB University, \\ Jalan Agatis, Kampus IPB Dramaga Bogor 16680, Indonesia \\ kDepartment of Animal and Rangeland Science, Oregon State University, Corvallis, OR 97333, USA \\ *Corresponding author: a.irawan@staff.uns.ac.id \\ (Received 25-11-2020; Revised 28-01-2021; Accepted 01-03-2021)
}

\begin{abstract}
This meta-analysis was conducted to investigate the effect of dietary propolis supplementation on broiler performance, carcass characteristics, and nutrient digestibility evaluated at the starter and finisher phases. An online literature search was conducted using scientific platforms of Science Direct, PubMed, and Google Scholar to identify the studies utilizing propolis as dietary supplementation in broiler chickens. A total of 39 publications comprising of 58 experiments met the inclusion criteria. A mixed model procedure for meta-analysis was performed, considering the studies as a random effect and levels of propolis as a fixed effect. Regression analysis suggested that average daily gain (ADG), body weight, and average daily feed intake (ADFI) at starter and finisher phases were quadratically affected by supplementing propolis in the diet $(\mathrm{p}<0.01)$. Propolis also lowered the feed conversion ratio $(F C R)$ throughout the periods $(\mathrm{p}<0.05)$. In addition, a positive effect of propolis inclusion was also observed on breast meat percentage $(p<0.05)$. However, there was a negative linear relationship between propolis and the digestibility of dry matter (DMD) and organic matter (OMD) $(p<0.01)$ at the starter period. Conversely, there was a linear increase in DMD $(p<0.05)$ and a tendency to improve apparent metabolizable energy (AME) and phosphorus digestibility at the finisher period $(p<0.10)$. Overall, it can be concluded that dietary propolis supplementation promoted better growth performance and feed efficiency when given at $\sim 1.66-2.13 \mathrm{~g} / \mathrm{kg}$ diets for starter and finisher phases in the broiler chickens. The effect of propolis on nutrient digestibility was positive at the finisher phase while it was detrimental at the starter phase.
\end{abstract}

Keywords: bioactive compounds; broiler chicken; growth promoter; nutrient utilization; propolis

\section{INTRODUCTION}

Demand for natural-based additive in modern broiler production is increasing, in line with the increasing consumer awareness of healthy animal products. In the past, broiler producers received many benefits from the use of antibiotics at sub-therapeutic doses as growth-promoting (AGPs) additive, particularly related to the effect on cost-effective production (Allen et al., 2013). However, since antibacterial resistance has become a global issue due to the extensive use of AGPs, their applications in the poultry feed industry have been prohibited massively (Abudabos et al., 2019). Since then, significant progress in investigating antibiotics alternatives for broiler chickens has been prompted by scientists worldwide, including the use of propolis, the resinous and balsamic substances produced by bees which have received a growing interest in the last decades.

Propolis is a complex resinous substance produced by honey bees for the purpose of building honeycombs in the hives and is known to contain more than 300 chemical compounds (Przybyłek \& Karpiński, 2019). 
Among the biological and pharmacological properties, polyphenols and terpenoids groups are considered to be the most potent antioxidant, antimicrobial, immunomodulatory, and anti-inflammatory compounds (Pimenta et al., 2015; Silva et al., 2017). There are two mechanisms of propolis in modulating broiler metabolism: the first mechanism is attributed to the direct action as antimicrobial activity. The second mechanism is related to the immune-stimulating effects, facilitating the activation of the natural defense system of the animal (Sforcin, 2016). In regard to its antibacterial effect, substances of propolis were reported to effectively disrupt the permeability of the cellular membrane and adenosine triphosphate (ATP) production of bacteria (Przybyłek \& Karpiński, 2019). In broiler, propolis supplementation is beneficial for balancing the microbial composition of the digestive system, whether offered in the form of extract or crude propolis (Eyng et al., 2017). The authors also suggest that propolis supplementation also has the potential to improve nutrient utilization by enhancement of enzyme secretion as well as absorptive functions. Another advantage is that propolis does not have any residue or toxic effect on the carcass, which is beneficial for human health (Denli et al., 2005).

In general, previous studies reported an improvement in immunological indices, intestinal microbial composition, and broiler performance by using a diet supplemented with propolis (Attia et al., 2014; Attia et al., 2017; Zafarnejad et al., 2017). Since promoting the growth of beneficial bacteria could enhance intestinal health, this mechanism is suggested to improve nutrient digestibility (Ao \& Choct, 2013; Seven et al., 2012). Moreover, it has been demonstrated that propolis supplementations reduce the negative effects of heat stress in broiler chickens due to their antioxidant properties as well as macrophages activation and antibody synthesis (Eyng et al., 2015). Since there are large variations in propolis properties according to their origins, different pieces of evidence may exist. For instance, Eyng et al. (2014) reported contrary results that the inclusion of propolis extract impaired digestive enzyme secretion at the pre-starter phase, especially sucrose activity, thus lowered broiler performance at this stage. However, a recovery effect was observed at the finisher phase reflected by the improvement effect in the broiler receiving propolis. Also, Eyng et al. (2017) did not find any effect on intestinal microbiota and broiler performance by supplementing both raw propolis and ethanolic extract of propolis, although they found changes in the caecal bacterial composition. From this point of view, inconsistent results from available studies need to be elucidated.

A quantitative review can facilitate to summarize and explain the factors causing the different effects. A meta-analysis is a statistical tool that is being increasingly popular to be used in the area of animal nutrition. This statistically robust method facilitates researchers to integrate available studies and summarize the effect of size from different studies quantitatively, thus increase statistical power and reduce publication bias (Sauvant et al., 2008). By integrating studies examining the effect of propolis inclusion in the broiler diets, it can contribute to explaining the gap of knowledge synthesized from this meta-analysis. Therefore, this study aimed to quantify the effect of diet supplemented with propolis on broiler performance, nutrient digestibility, and carcass characteristics according to inclusion levels using meta-analysis.

\section{MATERIALS AND METHODS}

\section{Literature Search}

Studies containing information about the use of propolis in broiler diet were retrieved from the online scientific database of Science Direct, PubMed Central, and Google Scholar (Table 1). In searching the literature, we used a combination of several keywords and Boolean statement as follow: "propolis" [MeSH Terms] OR "propolis" [All Fields] AND broiler [All Fields] AND performance [All Fields] AND digestibility [All Fields]. Relevant articles were downloaded according to their title and further reviewed for database development. Several inclusion criteria were determined in order to select the suited articles as well as to reduce the publication bias. To be eligible, the article has to be: (1) published in English in a peer-reviewed academic journal to ensure the quality; (2) reported the level of propolis supplementation in the diet; (3) reported the mean value, variations (standard deviation or standard error of means), number of replications, and number of birds used in the experiment; and (4) provided a clear methodology particularly the environmental situation. At this stage, articles that did not meet the prerequisite criteria were excluded from the study. Data were compiled with LibreOffice version 6.3.6.2. After carefully reviewing the database, a total of 39 studies met our pre-determined criteria and therefore were used for analysis. These studies are composed of 58 experiments consisting of 196 data lines.

The parameters included in the database were growth performance at the starter and finisher phases [e.g. body weight (BW), average daily gain (ADG), daily feed intake (DFI), feed conversion ratio (FCR), and mortality], nutrients digestibility [e.g., apparent metabolizable energy (AME), calcium digestibility (CD), crude-protein digestibility (CPD), ether-extract digestibility (EED), nitrogen digestibility (ND), dry-matter digestibility (DMD), organic-matter digestibility (OMD), and phosphorus digestibility (PD)], and carcass characteristics (carcass, breast, legs, wings, abdominal fat, cecum, cloaca, esophagus and crop, gizzard, heart, liver, proventriculus, spleen, and thymus).

\section{Statistical Analysis}

Data with different units were transformed into the same measurement units prior to analysis. The summary of the data was processed using the linear mixed model method (St-Pierre, 2001), whereas the experimental studies were declared as a random effect, and the level of supplemental propolis was set as fixed effects. The mathematical model of the linear mixed model is as follows: 
Table 1. Studies using propolis as an additive on broiler chickens included for meta-analysis

\begin{tabular}{|c|c|c|c|c|c|c|c|}
\hline \multirow{2}{*}{ No. } & \multirow{2}{*}{ Levels } & \multirow{2}{*}{ Strain } & \multirow{2}{*}{ Sex } & \multicolumn{3}{|c|}{ Period (day) } & \multirow{2}{*}{ References } \\
\hline & & & & Starter & Finisher & Total & \\
\hline 1 & $0-4000$ & ROSS 308 & Male & $1-28$ & $29-42$ & $1-42$ & Açıkgöz et al. (2005) \\
\hline 2 & $0-1000$ & ROSS 308 & As hatched & $1-21$ & $22-47$ & $1-47$ & Ziaran et al. (2005) \\
\hline 3 & $0-250$ & ROSS 308 & As hatched & $1-21$ & $22-42$ & $1-42$ & Shalmany \& Shivazad (2006) \\
\hline 4 & $0-1500$ & ROSS 308 & Male & $1-21$ & $22-42$ & $1-42$ & Tekeli et al. (2010) \\
\hline 5 & $0-5000$ & ROSS 308 & As hatched & - & - & $1-42$ & Seven \& Seven (2008) \\
\hline 5 & $0-3000$ & ROSS 308 & Mixed & $3-21$ & $22-41$ & $3-41$ & Seven et al. (2008) \\
\hline 6 & $0-3000$ & ROSS 308 & As hatched & - & - & $8-42$ & Khodanazary et al. (2011) \\
\hline 7 & $0-200$ & ROSS 308 & Male & $1-21$ & $22-42$ & $1-42$ & Daneshmand et al. (2012) \\
\hline 8 & $0-1000$ & ROSS 308 & As hatched & $3-21$ & $22-41$ & $3-41$ & Seven et al. (2012) \\
\hline 9 & $0-500$ & Cobb 500 & Male & $1-21$ & - & - & Eyng et al. (2014) \\
\hline 10 & $0-750$ & ROSS 308 & Male & $1-21$ & $22-42$ & $1-42$ & Mahmoud et al. (2013) \\
\hline 11 & $0-2500$ & ROSS 308 & Male & - & - & $1-28$ & Abbas (2014) \\
\hline 12 & $0-300$ & Arbor Acres & Mixed & $1-21$ & $22-35$ & $1-35$ & Attia et al. (2014) \\
\hline 13 & $0-500$ & Cobb 500 & Male & $1-21$ & - & $1-42$ & Duarte et al. (2014) \\
\hline 14 & $0-5000$ & Cobb 500 & Male & $1-21$ & - & $1-42$ & Eyng et al. (2014) \\
\hline 15 & $0-500$ & Cobb 500 & Mixed & - & - & $1-42$ & Abou-Zeid et al. (2015) \\
\hline 16 & $0-200$ & ROSS 308 & Male & $1-21$ & $22-42$ & $1-42$ & Daneshmand et al. (2015) \\
\hline 17 & $0-4000$ & Cobb 500 & Male & - & - & $1-21$ & Eyng et al. (2015) \\
\hline 18 & $0-200$ & ROSS 308 & As hatched & $1-21$ & $22-42$ & $1-42$ & Torki et al. (2015) \\
\hline 19 & $0-5000$ & Cobb 500 & Male & $1-21$ & - & $1-21$ & Eyng et al. (2017) \\
\hline 20 & $0-400$ & ROSS 308 & Mixed & $1-21$ & $22-42$ & $1-42$ & Haščík et al. (2016) \\
\hline 21 & $0-3000$ & ROSS 308 & Male & $1-21$ & $22-42$ & $1-42$ & Hosseini et al. (2016) \\
\hline 22 & $0-300$ & ROSS 308 & Male & $1-21$ & $22-42$ & $1-42$ & Gheisariet al. (2017) \\
\hline 23 & $0-570$ & ROSS 308 & Male & $1-21$ & $22-28$ & $1-28$ & Biavatti et al. (2003) \\
\hline 24 & $0-1000$ & ROSS 308 & Mixed & $1-21$ & $22-42$ & $1-42$ & Taheri et al. (2005) \\
\hline 25 & $0-1000$ & ROSS 308 & As hatched & $1-21$ & $22-42$ & $1-42$ & Seven et al. (2010) \\
\hline 26 & $0-3000$ & ROSS 708 & Male & - & - & $1-42$ & Mahmoud et al. (2017) \\
\hline 27 & $0-1200$ & ROSS 308 & Female & - & - & $16-20$ & Sahin \& Ozturk (2017) \\
\hline 28 & $0-2000$ & ROSS 308 & Male & $1-24$ & $25-42$ & $1-42$ & Shaddel-Tili et al. (2017) \\
\hline 29 & $0-4000$ & ROSS 308 & Male & $1-21$ & $22-42$ & $1-42$ & Chegini et al. (2018) \\
\hline 30 & $0-3000$ & ROSS 308 & Male & - & - & $1-35$ & Kinasih et al. (2018) \\
\hline 31 & $0-1000$ & ROSS 308 & Mixed & $1-21$ & $22-42$ & $1-42$ & Klarić et al. (2018) \\
\hline 32 & $0-1000$ & Cobb 500 & As hatched & $1-21$ & $22-42$ & $1-42$ & Al-Sultan et al. (2019) \\
\hline 33 & $0-500$ & Iraqi local rooster & Male & - & - & - & Khafaji et al. (2019) \\
\hline 34 & $0-400$ & ROSS 308 & Mixed & $1-21$ & $22-42$ & $1-42$ & Haščík et al. (2019) \\
\hline 35 & $0-3000$ & ROSS 308 & As hatched & $1-21$ & $22-42$ & $1-42$ & Hassan et al. (2018) \\
\hline 36 & $0-400$ & Cobb 500 & Mixed & $1-21$ & $22-49$ & $1-49$ & Rabie et al. (2018) \\
\hline 37 & $0-800$ & Cobb 500 & Mixed & - & - & - & Abdelsalam et al. (2019) \\
\hline 38 & $0-1000$ & ROSS 308 & Mixed & $1-21$ & $22-42$ & $1-42$ & Alani et al. (2019) \\
\hline 39 & $0-1000$ & ROSS 308 & Mixed & $1-21$ & $22-42$ & $1-42$ & Prakatur et al. (2019) \\
\hline
\end{tabular}

1) $Y_{i j}=\beta_{0}+\beta_{1}$ Level $_{i j}+$ Experiment $_{i}+$ Experiment $_{i}$ Level $_{i j}+\varepsilon_{i j}$

2) $Y_{i j}=\beta_{0}+\beta_{1}$ Level $_{i j}+\beta_{2}$ Level $_{i j}^{2}+$ Experiment $_{i}+$ Experiment $L_{i}$ evel $_{i j}+\varepsilon_{i j}$

where 1) is mathematical model of the linear mixed model (LMM) order $1 ; 2$ ) is a mathematical model of LMM order 2; fixed effect is $\beta_{0}+\beta_{1}$ Level $_{i j}$ (ordo 1 ) and $\beta_{0}+$ $\beta_{1}$ Level $_{i j}+\beta_{2}$ Level $^{2}$ (ordo 2); random effect is Experiment ${ }_{i}$ + Experiment $_{i}$ Level $_{i j}+\varepsilon_{i j}$ (ordo 1 and 2); $Y_{i j}$ is dependent variable, $\beta_{0}$ is value when level intersects the $Y$ axis for all random effect combinations; $\beta_{1}$ is coefficient of the 1st order level; $\beta_{2}$ is coefficient of the 2nd order level; Level $_{i j}$ is increased level of random effect; Experiment ${ }_{i}$ is experiment at $\mathrm{i}$, and $\varepsilon_{i j}$ is model error.

The statistical models used are p-values, root mean square errors (RMSE), and Akaike information criterion (AIC). The significance was denoted when $\mathrm{p}<0.05$ and when $0.05<p<0.10$, it was declared as a tendency. The data were analyzed using a script built using $\mathrm{R}$ version 3.6.3 software with the "nlme" package (Pinheiro et al., 2020; R Core Team 2020). 


\section{RESULTS}

\section{Broiler Performance and Carcass Characteristics}

In the present meta-analysis, the effect of propolis supplementation on broiler performance was evaluated during starter and finisher periods. As shown in Table 2, propolis supplementation linearly increased the ADG, BW, and DFI of broiler chickens both in starter and finisher phases, giving a significant improvement in final broiler performance $(\mathrm{p}<0.01)$. This study also suggested that there was a dependent relationship between daily gain with the levels of propolis supplementation, as shown with a significant quadratic effect (Table 2, $\mathrm{p}<0.05)$. In addition, feed conversion ratio (FCR) also decreased linearly as propolis inclusion increased at starter and finisher periods $(\mathrm{p}<0.01)$. The positive effect of propolis was also noticed on mortality throughout the period of broiler chickens as the mortality tends to decrease at starter and finisher periods and consequently at the final period in a quadratic manner $(p<0.1)$. When the carcass characteristics were evaluated, no effect was observed on carcass yield, abdominal fat, digestive organs, and most of the visceral organs such as liver, thymus, and hearth $(\mathrm{p}>0.05)$. However, breast meat and spleen weight linearly increased with increasing propolis supplementation $(\mathrm{p}<0.05)$.

\section{Nutrient Digestibility}

The effect of propolis supplementation on nutrient digestibility was investigated during the starter and finisher phases, where the regression models are presented in Table 3. At the starter phase (day 1 up to $21 \mathrm{~d}$ of age), increasing levels of propolis linearly reduced digestibility of dry matter (DMD) and organic matter (OMD) $(p<0.01)$. At the finisher phase, the DMD is quadratically affected by the levels of propolis $(p<0.01)$. OMD, on the other hand, tends to increase at a linear pattern $(\mathrm{p}<0.1)$ as propolis level increased. In addition, there was also a tendency to decrease crude protein digestibility (CPD) as a result of propolis supplementation $(p<0.1)$. In this study, we confirmed a marginal increase in apparent metabolizable energy (AME) as affected by propolis

Table 2. Regression equations on the effect of dietary propolis supplementation ( $\mathrm{mg} / \mathrm{kg}$ diet) on broiler chicken performances

\begin{tabular}{|c|c|c|c|c|c|c|c|c|c|c|c|c|c|}
\hline \multirow{2}{*}{$\begin{array}{l}\text { Outcome } \\
\text { variables }\end{array}$} & \multirow{2}{*}{ Unit } & \multirow{2}{*}{ Model } & \multirow{2}{*}{$\mathrm{N}$} & \multicolumn{4}{|c|}{ Parameter estimates } & \multicolumn{3}{|c|}{ Model estimates } & \multicolumn{3}{|c|}{ Interpretation } \\
\hline & & & & Intercept & $\mathrm{SE}_{\text {Intercept }}$ & Slope & $\mathrm{SE}_{\text {Slope }}$ & p-value & RMSE & $\mathrm{AIC}^{1}$ & Trend & $\mathrm{X}^{2}$ & $\mathrm{Y}^{3}$ \\
\hline \multicolumn{14}{|c|}{ Broiler performance at starter period } \\
\hline \multirow[t]{2}{*}{ Bodyweight } & $\mathrm{g}$ & Q & 103 & 723.7 & 32.9 & 439.6 & 132.11 & 0.001 & 2.42 & $1,205.2$ & Max. & 2,135 & 770.6 \\
\hline & & & & & & $-1,029.3$ & 320.55 & 0.002 & & & & & \\
\hline \multirow[t]{2}{*}{ ADG } & $\mathrm{g} / \mathrm{h} / \mathrm{d}$ & Q & 105 & 29.6 & 1.2 & 22.9 & 6.02 & $<0.001$ & 2.49 & 571.6 & Max. & 2,245 & 32.14 \\
\hline & & & & & & -50.9 & 14.64 & 0.001 & & & & & \\
\hline \multirow[t]{2}{*}{ DFI } & $\mathrm{g} / \mathrm{h} / \mathrm{d}$ & Q & 101 & 47.1 & 2.1 & 20.8 & 6.25 & 0.001 & 2.15 & 585.8 & Max. & 2,173 & 49.40 \\
\hline & & & & & & -47.9 & 15.15 & 0.002 & & & & & \\
\hline \multirow[t]{2}{*}{ FCR } & & $\mathrm{L}$ & 101 & 1.59 & 0.03 & -0.40 & 0.22 & 0.071 & 2.39 & -140.8 & Min. & 2,405 & 1.55 \\
\hline & & & & & & 0.83 & 0.53 & 0.121 & & & & & \\
\hline \multirow[t]{2}{*}{ Mortality } & $\%$ & Q & 8 & 4.25 & 3.29 & -319.5 & 149.00 & 0.099 & 0.95 & 47.9 & Min. & 519.9 & -4.05 \\
\hline & & & & & & $3,072.2$ & $1,527.57$ & 0.115 & & & & & \\
\hline \multicolumn{14}{|c|}{ Broiler performance at finisher period } \\
\hline \multirow[t]{2}{*}{ Bodyweight } & $\mathrm{g}$ & Q & 86 & $2,064.2$ & 61.43 & 2,203.8 & 463.09 & $<0.001$ & 1.87 & $1,151.2$ & Max. & 1,762 & 2,258 \\
\hline & & & & & & $-6,254.0$ & 1,401.6 & $<0.001$ & & & & & \\
\hline \multirow[t]{2}{*}{ ADG } & $\mathrm{g} / \mathrm{h} / \mathrm{d}$ & Q & 81 & 73.4 & 3.84 & 62.4 & 15.39 & $<0.001$ & 1.57 & 564.9 & Max. & 1,656 & 78.6 \\
\hline & & & & & & -188.5 & 46.86 & $<0.001$ & & & & & \\
\hline \multirow[t]{2}{*}{ DFI } & $\mathrm{g} / \mathrm{h} / \mathrm{d}$ & Q & 77 & 152.4 & 7.92 & 45.9 & 32.82 & 0.168 & 1.75 & 649.81 & Max. & 1,451 & 155.8 \\
\hline & & & & & & -158.3 & 99.45 & 0.118 & & & & & \\
\hline \multirow[t]{2}{*}{ FCR } & & Q & 77 & 2.08 & 0.04 & -1.05 & 0.51 & 0.045 & 2.00 & -51.38 & Min. & 2,041 & 1.97 \\
\hline & & & & & & 2.5870 & 1.53 & 0.097 & & & & & \\
\hline \multirow[t]{2}{*}{ Mortality } & $\%$ & Q & 8 & 7.89 & 4.84 & -127.8 & 36.5 & 0.025 & 0.95 & 32.5 & Min. & 426.4 & 5.16 \\
\hline & & & & & & $1,498.6$ & 379.3 & 0.017 & & & & & \\
\hline \multicolumn{14}{|c|}{ Broiler performance at overall period } \\
\hline \multirow[t]{2}{*}{ Bodyweight } & $\mathrm{g}$ & Q & 151 & $2,143.7$ & 85.1 & 835.9 & 242.02 & 0.001 & 2.08 & $2,034.9$ & Max. & $2,322.4$ & $2,240.8$ \\
\hline & & & & & & $-1,799.7$ & 585.73 & 0.003 & & & & & \\
\hline \multirow[t]{2}{*}{ ADG } & $\mathrm{g} / \mathrm{h} / \mathrm{d}$ & Q & 151 & 61.2 & 4.4 & 24.1 & 7.03 & 0.001 & 1.90 & $1,019.3$ & Max. & $2,273.2$ & 63.9 \\
\hline & & & & & & -52.9 & 16.71 & 0.002 & & & & & \\
\hline \multirow[t]{2}{*}{ DFI } & $\mathrm{g} / \mathrm{h} / \mathrm{d}$ & Q & 147 & 140.7 & 20.8 & 20.1 & 9.91 & 0.046 & 2.22 & 1,195.4 & Max. & $2,350.1$ & 143.0 \\
\hline & & & & & & -42.7 & 23.54 & 0.073 & & & & & \\
\hline \multirow[t]{2}{*}{ FCR } & & Q & 147 & 2.1 & 0.1 & -0.4 & 0.23 & 0.065 & 2.13 & -45.5 & Min. & $2,422.2$ & 2.01 \\
\hline & & & & & & 0.9 & 0.54 & 0.108 & & & & & \\
\hline Mortality & $\%$ & Q & 27 & 5.9 & 1.7 & -9.2 & 4.68 & 0.065 & 1.28 & 144.9 & Neg. & & \\
\hline
\end{tabular}

Note: $\mathrm{ADG}=$ Average daily gain; $\mathrm{AIC}=$ Akaike information criterion; DFI=Daily feed intake; $\mathrm{FCR}=$ feed conversion ratio; Int= Intercept; $\mathrm{L}=\mathrm{Linear} ; \mathrm{Max} .=$ maximum; Min.= minimum; $\mathrm{N}=$ number of data; Neg. $=$ Negative; $\mathrm{Q}=$ quadratic; $\mathrm{RMSE}=$ Root mean square errors; $\mathrm{SE}=\mathrm{standard}^{\mathrm{error}} \mathrm{AIC}{ }^{1}=\mathrm{an}$ estimator of the relative quality of statistical models for a given set of data; $\mathrm{X}^{2}=$ predicted optimal level of dietary propolis supplementation (mg/ $\mathrm{kg}$ ); $\mathrm{Y}^{3}=$ predicted optimal outcome of the response parameter as influenced by dietary propolis supplementation (mg/kg). 
Table 3. Regression equations on the effect of dietary propolis supplementation ( $\mathrm{mg} / \mathrm{kg}$ diet) on carcass characteristics (\% BW) of broiler chickens

\begin{tabular}{|c|c|c|c|c|c|c|c|c|c|c|c|c|c|}
\hline \multirow{2}{*}{ No. } & \multirow{2}{*}{ Variables } & \multirow{2}{*}{ Model } & \multirow{2}{*}{$\mathrm{N}$} & \multicolumn{4}{|c|}{ Parameter estimates } & \multicolumn{3}{|c|}{ Model estimates } & \multicolumn{3}{|c|}{ Interpretation } \\
\hline & & & & Intercept & $S E_{\text {Intercept }}$ & Slope & SE ${ }_{\text {Slope }}$ & p-value & RMSE & $\mathrm{AIC}^{1}$ & Trend & $\mathrm{X}^{2}$ & $\mathrm{Y}^{3}$ \\
\hline 1. & Carcass & $\mathrm{L}$ & 83 & 74.12 & 1.68 & 2.33 & 1.45 & 0.114 & 2.00 & 360.9 & Pos. & & \\
\hline \multirow[t]{2}{*}{2.} & Breast & Q & 34 & 29.26 & 2.39 & 9.44 & 3.03 & 0.005 & 1.36 & 129.4 & Max. & $3,284.5$ & 30.8 \\
\hline & & & & & & -14.36 & 6.98 & 0.051 & & & & & \\
\hline 3. & Legs & $\mathrm{L}$ & 20 & 27.60 & 4.13 & -2.74 & 1.29 & 0.053 & 1.49 & 76.9 & Neg. & & \\
\hline 4. & Wings & $\mathrm{L}$ & 24 & 16.35 & 3.46 & 3.00 & 2.32 & 0.212 & 1.73 & 113.4 & Pos. & & \\
\hline 5. & Abdominal fat & $\mathrm{L}$ & 59 & 1.50 & 0.12 & -0.10 & 0.31 & 0.752 & 1.40 & 29.8 & Neg. & & \\
\hline 6. & Cecum & $\mathrm{L}$ & 15 & 0.34 & 0.09 & -0.12 & 0.13 & 0.356 & 1.12 & -40.5 & Neg. & & \\
\hline 7. & Cloaca & $\mathrm{L}$ & 11 & 0.24 & 0.01 & 0.07 & 0.04 & 0.151 & 1.22 & -51.3 & Pos. & & \\
\hline 8. & $\begin{array}{l}\text { Esophagus and } \\
\text { crop }\end{array}$ & $\mathrm{L}$ & 20 & 0.42 & 0.07 & 0.004 & 0.03 & 0.906 & 1.19 & -59.9 & Pos. & & \\
\hline 9. & Gizzard & $\mathrm{L}$ & 69 & 1.64 & 0.09 & 0.06 & 0.09 & 0.556 & 1.45 & -48.8 & Pos. & & \\
\hline 10 & Heart & $\mathrm{L}$ & 52 & 0.53 & 0.09 & 0.10 & 0.08 & 0.222 & 1.44 & -135.8 & Pos. & & \\
\hline 11. & Liver & $\mathrm{L}$ & 82 & 2.17 & 0.11 & -0.04 & 0.14 & 0.776 & 1.44 & -1.6 & Neg. & & \\
\hline 12. & Proventriculus & $\mathrm{L}$ & 28 & 0.44 & 0.06 & -0.03 & 0.06 & 0.599 & 1.04 & -75.9 & Neg. & & \\
\hline 13. & Spleen & $\mathrm{L}$ & 44 & 0.13 & 0.01 & 0.07 & 0.02 & 0.008 & 1.30 & -211.6 & Pos. & & \\
\hline 14. & Thymus & $\mathrm{L}$ & 24 & 0.39 & 0.09 & 0.01 & 0.13 & 0.956 & 1.46 & -47.8 & Pos. & & \\
\hline
\end{tabular}

Note: $\mathrm{AIC}=$ Akaike information criterion; $\mathrm{N}=$ number of data; Neg.= Negative; Pos.= Positive; $\mathrm{Q}=$ quadratic; $\mathrm{RMSE}=\mathrm{Root}$ mean square errors; $\mathrm{SE}=$ standard error; $\mathrm{AIC}^{1}=$ an estimator of the relative quality of statistical models for a given set of data; $\mathrm{X}^{2}=$ predicted optimal level of dietary propolis supplementation $(\mathrm{mg} / \mathrm{kg}) ; \mathrm{Y}^{3}=$ predicted optimal outcome of the response parameter as influenced by dietary propolis supplementation (mg/kg); $\%$ BW= \% body weight.

Table 4. Regression equations on the effect of dietary propolis supplementation ( $\mathrm{mg} / \mathrm{kg}$ diet) on nutrient digestibility (\%)

\begin{tabular}{|c|c|c|c|c|c|c|c|c|c|c|c|c|c|}
\hline \multirow{2}{*}{ Variables } & \multirow{2}{*}{ Unit } & \multirow{2}{*}{ Model } & \multirow{2}{*}{$\mathrm{N}$} & \multicolumn{4}{|c|}{ Parameter estimates } & \multicolumn{3}{|c|}{ Model estimates } & \multicolumn{3}{|c|}{ Interpretation } \\
\hline & & & & Intercept & $S E_{\text {Intercept }}$ & Slope & $\mathrm{SE}_{\text {Slope }}$ & $\mathrm{p}$-value & RMSE & $\mathrm{AIC}^{1}$ & Trend & $X^{2}$ & $Y^{3}$ \\
\hline \multicolumn{14}{|c|}{ Nutrient digestibility in the starter period } \\
\hline DMD & $\%$ & $\mathrm{~L}$ & 6 & 74.51 & $3.74 \mathrm{E}-15$ & -1.25 & 8.01E-17 & $<0.001$ & 297.45 & -398.0 & Neg. & & \\
\hline OMD & $\%$ & $\mathrm{~L}$ & 6 & 77.00 & $1.45 \mathrm{E}-15$ & -0.95 & 8.01E-17 & $<0.001$ & 297.45 & -403.7 & Neg. & & \\
\hline \multicolumn{14}{|c|}{ Nutrient digestibility in the finisher period } \\
\hline DMD & $\%$ & Q & 10 & 75.78 & 3.35 & -25.66 & 3.57 & 0.006 & 0.74 & 46.56 & Min. & 2,381.1 & 72.7 \\
\hline \multirow[t]{2}{*}{ OMD } & $\%$ & Q & 12 & 77.52 & 2.75 & -28.04 & 9.92 & 0.047 & 0.94 & 65.81 & Min. & $2,401.4$ & 74.2 \\
\hline & & & & & & 58.39 & 22.84 & 0.063 & & & & & \\
\hline \multirow[t]{2}{*}{ CPD } & $\%$ & Q & 12 & 74.29 & 4.90 & -37.73 & 17.12 & 0.092 & 0.88 & 79.29 & Min. & $2,453.5$ & 69.7 \\
\hline & & & & & & 76.89 & 39.44 & 0.123 & & & & & \\
\hline \multirow[t]{2}{*}{ EED } & $\%$ & Q & 10 & 81.99 & 4.02 & -31.07 & 6.11 & 0.015 & 0.75 & 53.72 & Min. & 2,127.4 & 78.7 \\
\hline & & & & & & 73.02 & 14.08 & 0.014 & & & & & \\
\hline ND & $\%$ & $\mathrm{~L}$ & 10 & 57.27 & 2.59 & 12.53 & 5.28 & 0.055 & 0.97 & 61.34 & Pos. & & \\
\hline CAD & & & & & & 8.64 & 8.82 & 0.372 & & & & & \\
\hline PD & $\%$ & $\mathrm{~L}$ & 10 & 48.84 & 0.55 & 3.50 & 1.31 & 0.037 & 0.97 & 32.23 & Pos. & & \\
\hline AME & $\%$ & $\mathrm{~L}$ & 10 & 11.62 & 0.19 & 1.43 & 0.65 & 0.071 & 1.12 & 15.17 & Pos. & & \\
\hline
\end{tabular}

Note: $\mathrm{AIC}=$ Akaike information criterion; $\mathrm{AME}=$ apparent metabolizable energy $\mathrm{CAD}=$ calcium digestibility; $\mathrm{CPD}=\mathrm{crude}$ protein digestibility; $\mathrm{DMD}=$ dry matter digestibility; $\mathrm{EED}=$ ether extract digestibility; $\mathrm{ND}=$ Nitrogen digestibility; $\mathrm{OMD}=\mathrm{Organic}$ matter digestibility; $\mathrm{PD}=\mathrm{Phosphor}$ digestibility; L= Linear; Max.= maximum; Min.= minimum; N= number of data; Neg.= Negative; $Q=$ quadratic; $\mathrm{RMSE}=\mathrm{Root}$ mean square errors; $\mathrm{SE}=$ standard error; $\mathrm{AIC}^{1}=$ an estimator of the relative quality of statistical models for a given set of data; $\mathrm{X}^{2}=$ predicted optimal level of dietary propolis supplementation $(\mathrm{mg} / \mathrm{kg}) ; \mathrm{Y}^{3}=$ predicted optimal outcome of the response parameter as influenced by dietary propolis supplementation (mg/kg).

inclusion $(p<0.07)$, while a more positive effect was observed on phosphorus digestibility (PD) and ether extract digestibility (EED) which showed a significantly increased at the linear pattern $(\mathrm{p}<0.05)$.

\section{DISCUSSION}

\section{Broiler Performance and Carcass Characteristics}

Among naturally occurring feed additives, propolis has been acknowledged for its beneficial effect on broiler growth and health. As confirmed in this meta-analysis, our findings supported previous experiments in which propolis improved broiler performance both in normal conditions and when the animals were situated under heat stress challenge (Tatli Seven et al., 2008; Seven et al., 2012). The explanation regarding the positive impact of propolis incorporated in the diet on the broiler chicken performances is attributed to the multiple mechanisms associated with active compounds presented in the propolis. Propolis contains a very complex chemical composition (Abdelsameea et al., 2013), including vita- 
mins, minerals, amino acids, and a number of bioactive compounds (Attia et al., 2014; Nasution et al., 2015; Attia et al., 2017). The beneficial effect of phenolic compounds presented in the propolis is known to have multiple pharmacological functions, such as antibacterial, immunomodulator, and antioxidants (Wang et al., 2004; Dziedzic et al., 2013; Eyng et al., 2015). The presence of vitamins, amino acids, and trace elements such as Zn also contributed to the improved growth performance of poultry (Seven et al., 2012; Hidayat et al., 2020).

As an antioxidant, several authors have reported that propolis could alleviate the negative effect of heat stress and improved antioxidant parameters such as the activities of superoxide dismutase (SOD), malondialdehyde (MDA), and catalase (CAT) (Seven et al., 2012). Improvement of antioxidant status can further promote body protein synthesis, decrease oxidative stress, and it is can also enhance the digestive enzyme activity (Seven et al., 2012; Attia et al., 2017). In addition, the immunomodulatory effect of propolis allows broiler chickens to activate the macrophages and stimulate antibody secretion as well as improve lymphoid organ weight (Eyng et al., 2015), thereby improving the gut health of broiler chickens (Kleczek et al., 2014). Intestinal macrophages are the first phagocytic cells responsible for initiating and developing the innate immune system by inhibiting pathogens as well as clearing the bacterial metabolite products that is essential to protect against prolonged inflammation and to maintain immune homeostasis (Wang et al., 2019).

Furthermore, these mechanisms play an important role in improving the intestinal health of chickens, where the process of nutrients absorption from the digested feed is carried out there. Temizer et al. (2017) reported that propolis could perform an anti-bacterial function, thereby reducing the number of pathogenic bacteria in the gut, as reported by Kačániová et al. (2012). The function of propolis as an anti-bacterial has an effect on improving intestinal health, which in turn increases the absorption of nutrients by the intestine (Tayeb \& Sulaiman, 2014) so that the effect is to increase the efficiency of using feed as shown in this study.

\section{Nutrient Digestibility}

It has been suggested that propolis could indirectly improve nutrient digestibility (Eyng et al., 2014). This effect is attributable to the role of propolis to modulate intestinal bacteria by enriching beneficial bacteria and suppressing pathogenic bacteria (Guo et al., 2003). A good bacterial composition can promote the secretion of digestive enzymes and the immune system, thus improve nutrient digestion and absorption in the intestine (Romier et al., 2009). There is a well-explained mechanism regarding the effect of microbial stimulation on enzyme secretion. Modulation of intestinal microbiota to promote a higher beneficial bacterial population provides several advantages. First, good bacteria can produce antimicrobial substances such as bacteriocins and short-chain fatty acids (SCFA) that can inhibit the growth of pathogens by disrupting the environment for the growth of pathogenic microbes (Jha et al., 2020).
Second, the bacteria are able to secrete extracellular enzymes such as amylase, xylanase, protease, and lipase. In addition, balancing microbial population also contribute to improving intestinal integrity and immunity (Oakley et al., 2016). Moreover, active compounds of propolis such as flavonoids were also suggested to have a growth hormone activity because they have an aglycone hydroxyl group (Przybyłek \& Karpiński, 2019).

In the present study, we found contrary results with the available literature, especially at the starter phase, whereas propolis decreased the digestibility of $\mathrm{DM}$ and OM. However, these results were in agreement with the study of Eyng et al. (2014), who reported a detrimental effect of propolis on broiler chickens during the first week of life. According to the literature, however, we did not find any effect on enzyme secretion and activity since there was no available information. Thus, we suggested that the mechanism underlying how propolis disrupts DM, OM, and CP digestibility and broiler growth can be connected with enzyme secretion and the negative effect of propolis on palatability. In the first week of life, broilers secrete very low digestive enzymes (Noy \& Sklan, 1999). Thus they need a diet with easily degradable ingredients such as broken rice, and soy-protein isolate to stimulate indigenous enzyme secretion and activity (Ebling et al., 2015). Introducing a diet containing various bioactive compounds was less favorable to pre-starter broilers that may disrupt enzyme secretion to degrade the feed to release nutrients. The second reason is regarding the negative effect of propolis on palatability. In these regards, studies reported that propolis inclusion reduced feed intake on broilers (Seven et al., 2008; Eyng et al., 2014). Another study demonstrated that supplementing a diet with a high level of propolis suppressed protein digestion and growth (Açikgöz et al., 2005). The reason to elucidate the adverse effect of propolis on DM, OM, and CP digestibility is that antibiotics or most alternatives do not directly benefit nutrient digestibility (Mountzouris et al., 2010). In the case of increasing nutrient utilization caused by AGP, it was promoted by reducing metabolic activities of the digestive bacteria (Miles et al., 2006). Instead, the protective effect in the intestinal barrier resulted from alternative AGP had different modes of action whereas consequently required a higher energy cost by microbes for their growth (Attia et al., 2017).

For the finisher phase, most of the previous findings where dietary propolis improved nutrient digestibility (Seven et al., 2012; Chegini et al., 2019) were confirmed in the present results, especially for EE and phosphorus digestibility. There were some possible reasons explaining how propolis or its properties improved nutrient utilization in the finisher phase. First, it can be related to the enzyme stimulating effect. Seven et al. (2012) found a remarkable increase in digestive enzyme activities of saccharase, amylase, and phosphatase on broiler chickens treated with a propolis-supplemented diet. This effect was not found in the starter phase, probably because enzyme secretion in the starter period is very low (Noy \& Sklan, 1999), thus adding a less palatable additive such as propolis decreased nutrient digestion as was shown in the current result (Table 3). 
Second, antioxidant effects could also partially explain the improvement of protein digestibility by interfering with oxidative protein denaturation. Moreover, propolis also exhibited a synergistic effect for protective actions on the intestinal barrier as a result of the ability of their substances such as phenolic compounds and flavonoids in modulating the gut ecosystem, enhancing absorptive capacity thus increase nutrient absorption (Prakatur et al., 2019). To support this theoretical reason, there were a number of pieces of evidence showing a significant improvement in length, high, and wide of the villi in the duodenum, jejunum, and ileum of broiler chickens receiving propolis treatment in their diet (Wang et al., 2007; Tekeli et al., 2010; Eyng et al., 2014; Prakatur et al., 2019). These parameters indicate a higher proliferation in the intestinal mucosa, whereas it is a clear indicator of better nutrient utilization. Furthermore, this result was also highly related to the major findings that propolis inclusion improved broiler performance at the finisher phase (Eyng et al., 2014).

\section{CONCLUSION}

Dietary propolis supplementation was effective to improve broiler chicken performances during the starter and finisher periods. The most optimum supplementary levels for to obtain optimum body weight and feed conversion ratio were between 1.66$2.13 \mathrm{~g} / \mathrm{kg}$ diets. Dietary propolis supplementation was also effective to improve nutrient digestibility at the finisher phase rather than the starter phase as reflected by the substantial increase in phosphorus digestibility. However, as the effect of increasing propolis supplementation in the starter phase was negative, it can be taken into consideration for future studies.

\section{CONFLICT OF INTEREST}

The authors (i.e., Nahrowi and Anuraga Jayanegara) serve as editorial boards of the Tropical Animal Science Journal, but they have no role in the decision to publish this article. The authors also declare that there is no conflict of interest with any financial, personal, or other relationships with other people or organization related to the material discussed in the manuscript.

\section{REFERENCES}

Abbas, R. J. 2014. Effect of dietary supplementation with differing levels of propolis on productivity and blood parameters in broiler chicks. Basrah Journal of Veterinary Research 1:164-180. https://doi.org/10.33762/bvetr.2014.98808

Abdelsameea, A. A., L. A. Mahgoub, \& S. M. A. Raouf. 2013. Study of the possible hepatoprotective effect of propolis against the hepatotoxic effect of atorvastatin in albino rats. ZUMJ 19:388-396. https://doi.org/10.21608/zumj.2013.4306

Abdelsalam, A. M., A. Abd ElAzim, A. M. R. Othman, \& E. M. Omar. 2019. Blood hematological and biochemical parameters and humoral immunity as affected by added dietary propolis supplementation of Cobb broiler chicks. Egypt. J. Nutr. Feed. 22:215-221. https://doi.org/10.21608/ ejnf.2019.103495
Abou-Zeid, A., S. El-Damarawy, Y. Mariey, \& S. El-Kasass. 2015. Effect of dietary propolis supplementation on performance and activity of antioxidant enzymes in broiler chickens. Egypt. J. Nutr. Feed. 18:391-400. https://doi. org/10.21608/ejnf.2015.104498

Abudabos, A. M., E. O. S. Hussein, M. H. Ali, \& M. Q. AlGhadi. 2019. The effect of some natural alternative to antibiotics on growth and changes in intestinal histology in broiler exposed to Salmonella challenge. Poult. Sci. 98:14411446. https://doi.org/10.3382/ps/pey449

Açikgöz, Z., B. Yücel, \& Ö. Altan. 2005. The effects of propolis supplementation on broiler performance and feed digestibility. Arch. Geflugelk. 69:117-122. https://doi.org/10.1590/ S0103-90161998000100024

Alani, A. A. T., A. S. A. Alheeti, \& E. N. S. Alani. 2019. Comparison between effect of adding propolis and antibiotic in in broiler chickens on productive performance and carcass traits. IOP Conf. Ser. Earth Environ. Sci. 388:012032. https://doi.org/10.1088/1755-1315/388/1/012032

Allen, H. K., U. Y. Levine, T. Looft, M. Bandrick, \& T. A. Casey. 2013. Treatment, promotion, commotion: Antibiotic alternatives in food-producing animals. Trends Microbiol. 21:114-119. https://doi.org/10.1016/j.tim.2012.11.001

Al-Sultan, S. I., S. M. Abdel-Raheem, S. M. S. Abd-Allah, \& A. M. Edris. 2019. Alleviation of chronic heat stress in broilers by dietary supplementation of novel feed additive combinations. Slov. Vet. Res. 56:269-279. https://doi. org/10.26873/SVR-766-2019

Ao, Z. \& M. Choct. 2013. Oligosaccharides affect performance and gut development of broiler chickens. AsianAustralas. J. Anim. Sci. 26:116-121. https://doi.org/10.5713/ ajas.2012.12414

Attia, Y.A., A.E.A. Al-Hamid, M.S. Ibrahim, M.A. Al-Harthi, F. Bovera, \& A.S. Elnaggar. 2014. Productive performance, biochemical and hematological traits of broiler chickens supplemented with propolis, bee pollen, and mannan oligosaccharides continuously or intermittently. Livest. Sci. 164:87-95. https://doi.org/10.1016/j.livsci.2014.03.005

Attia, Y. A., H. Al-Khalaifah, M. S. Ibrahim, A. E. A. Al-Hamid, M. A. Al-Harthi, \& A. El-Naggar. 2017. Blood hematological and biochemical constituents, antioxidant enzymes, immunity and lymphoid organs of broiler chicks supplemented with propolis, bee pollen and mannan oligosaccharides continuously or intermittently. Poult. Sci. 96:41824192. https://doi.org/10.3382/ps/pex173

Biavatti, M. W., M. H. Bellaver, L. Volpato, C. Costa, \& C. Bellaver. 2003. Preliminary studies of alternative feed additives for broilers: Alternanthera brasiliana extract, propolis extract and linseed oil. Rev. Bras. Cienc. Avic. 5:147-151. https://doi.org/10.1590/S1516-635X2003000200009

Chegini, S., A. Kiani, \& H. Rokni. 2018. Alleviation of thermal and overcrowding stress in finishing broilers by dietary propolis supplementation. Ital. J. Anim. Sci. 17:377-385. https://doi.org/10.1080/1828051X.2017.1360753

Chegini, S., A. Kiani, B. Parizadian Kavan, \& H. Rokni. 2019. Effects of propolis and stocking density on growth performance, nutrient digestibility, and immune system of heatstressed broilers. Ital. J. Anim. Sci. 18:868-876. https://doi. org/10.1080/1828051X.2018.1483750

Daneshmand, A., G. H. Sadeghi, \& A. Karimi. 2012. The effects of a combination of garlic, oyster mushroom and propolis extract in comparison to antibiotic on growth performance, some blood parameters and nutrients digestibility of male broilers. Rev. Bras. Cienc. Avic. 14:141-147. https:// doi.org/10.1590/S1516-635X2012000200009

Daneshmand, A., G. H. Sadeghi, A. Karimi, A. Vaziry, \& S. A. Ibrahim. 2015. Evaluating complementary effects of ethanol extract of propolis with the probiotic on growth performance, immune response and serum metabolites in 
male broiler chickens. Livest. Sci. 178:195-201. https://doi. org/10.1016/j.livsci.2015.04.012

Duarte, C. R. A., C. Eyng, A. E. Murakami, \& T. C. Santos. 2014. Intestinal morphology and activity of digestive enzymes in broilers fed crude propolis. Can. J. Anim. Sci. 94:105-114. https://doi.org/10.4141/cjas2013-059

Dziedzic, A., R. Kubina, R. D. Wojtyczka, A. Kabala-Dzik, M. Tanasiewicz, \& T. Morawiec. 2013. The antibacterial effect of ethanol extract of polish propolis on mutans streptococci and lactobacilli isolated from saliva. Evid. Based Complement. Alternat. Med. 2013:1-12. https://doi. org/10.1155/2013/681891

Denli, M., S. Cankaya, S. Silici, F. Okan, \& A. N. Uluocak. 2005. Effect of dietary addition of Turkish propolis on the growth performance, carcass characteristics and serum variables of quail (Coturnix coturnix japonica). AsianAustralas. J. Anim. Sci. 18:848-854. https://doi.org/10.5713/ ajas.2005.848

Ebling, P. D., A. M. Kessler, A. P. Villanueva, G. C. Pontalti, G. Farina, \& A. M. L. Ribeiro. 2015. Rice and soy protein isolate in pre-starter diets for broilers. Poult. Sci. 94:27442752. https://doi.org/10.3382/ps/pev279

Eyng, C., A. E. Murakami, C. R. A. Duarte, \& T. C. Santos. 2014. Effect of dietary supplementation with an ethanolic extract of propolis on broiler intestinal morphology and digestive enzyme activity. J. Anim. Physiol. Anim. Nutr. (Berl). 98:393-401. https://doi.org/10.1111/jpn.12116

Eyng, C., A. E. Murakami, A. A. Pedroso, C. R. A. Duarte, \& K. P. Picoli. 2017. Caecal microbiota of chickens fed diets containing propolis. J. Anim. Physiol. Anim. Nutr. 101:484492. https://doi.org/10.1111/jpn.12570

Eyng, C., A. E. Murakami, T. C. Santos, T. G. V. Silveira, R. B. Pedroso, \& D. A. L. Lourenço. 2015. Immune responses in broiler chicks fed propolis extraction residue-supplemented diets. Asian-Australas. J. Anim. Sci. 28:135-142. https:// doi.org/10.5713/ajas.14.0066

Gheisari, A., S. Shahrvand, \& N. Landy. 2017. Effect of ethanolic extract of propolis as an alternative to antibiotics as a growth promoter on broiler performance, serum biochemistry, and immune responses. Vet. World. 10:249-254. https://doi.org/10.14202/vetworld.2017.249-254

Guo, F.C., B.A. Williams, R.P. Kwakkel, \& M.W.A. Verstegen. 2003. In vitro fermentation characteristics of two mushroom species, an herb, and their polysaccharide fractions, using chicken cecal contents as inoculum. Poult. Sci. 82:1608-1615. https://doi.org/10.1093/ps/82.10.1608

Hascik, P., L. Trembecká, M. Bobko, M. Kacaniova, J. Cubon, S. Kunova, \& O. Bucko. 2016. Effect of diet supplemented with propolis extract and probiotic additives on performance, carcass characteristics and meat composition of broiler chickens. Potravinarstvo 10:223-231. https://doi. org/10.5219/581

Hascik, P., A. Pavelkova, H. Arpasova, J. Cubon, M. Kacaniova, \& S. Kunová. 2019. The effect of bee products and probiotic on meat performance of broiler chickens. J. Microbiol. Biotechnol. Food Sci. 9:88-92. https://doi.org/10.15414/ jmbfs.2019.9.1.88-92

Hassan, R. I. M., G. M. M. Mosaad, \& H. Y. Abd El-Wahab. 2018. Effect of feeding propolis on growth performance of broilers. J. Adv. Vet. Res. 8:66-72.

Hidayat, C., Sumiati, A. Jayanegara, \& E. Wina. 2020. Effect of zinc on the immune response and production performance of broilers: a meta-analysis. Asian-Australas. J. Anim. Sci. 33:465-479. https://doi.org/10.5713/ajas.19.0146

Hosseini, S.M., M. V. Azghandi, S. Ahani, \& R. Nourmohammadi. 2016. Effect of bee pollen and propolis (bee glue) on growth performance and biomarkers of heat stress in broiler chickens reared under high ambient temperature. J. Anim. Feed Sci. 25:45-50. https:// doi.org/10.22358/jafs/65586/2016

Jha, R., R. Das, S. Oak, \& P. Mishra. 2020. Probiotics (DirectFed Microbials) in poultry nutrition and their effects on nutrient utilization, growth and laying performance, and gut health: a systematic review. Animals 10:1863. https:// doi.org/10.3390/ani10101863

Kačániová, M., K. Rovná, H. Arpášová, J. Čuboň, L. Hleba, J. Pochop, S. Kunová, \& P. Hašč́k. 2012. In vitro and In vivo antimicrobial activity of propolis on the microbiota from gastrointestinal tract of chickens. J. Environ. Sci. Heal. Part A. 47:1665-1671. https://doi.org/10.1080/10934529.201 2.687248

Khafaji, S. S. O., T. K. ALjanabi, \& S. M. Suhailaltaie. 2019. Evaluation the impact of different levels of propolis on some reproductive features in iraqi local roosters. Adv. Anim. Vet. Sci. 7:82-87. https://doi.org/10.17582/journal. aavs/2019/7.2.82.87

Khodanazary, A., A. Tatar \& M. Khezri. 2011. Effects of different dietary levels of propolis on performance, carcass characteristics and immunity response of broiler chickens. J. Ethnopharmacol. 2:80-83.

Kinasih, I., U. Julita, Y. Suryani, T. Cahyanto, D. S. Annisa, A. Yuliawati, \& R. E. Putra. 2018. Addition of black soldier fly larvae (Hermetia illucens L.) and propolis to broiler chicken performance. IOP Conf. Ser. Earth Environ. Sci. 187:012026. https://doi.org/10.1088/1755-1315/187/1/012026

Klarić, I., M. Domaćinović, V. Šerić, I. Miškulin, M. Pavić, \& K. Paradinović. 2018. Effects of bee pollen and propolis on performance, mortality, and some haematological blood parameters in broiler chickens. Slov. Vet. Res. 55:23-34. https://doi.org/10.26873/SVR-385-2018

Kleczek, K., E. Wilkiewicz-Wawro, K. Wawro, W. Makowski, D. Murawska, \& M. Wawro. 2014. The effect of dietary propolis supplementation on the growth performance of broiler chickens. Pol. J. Nat. Sci. 29:105-117.

Mahmoud, U. T., M. A. Abdel-Rahman, \& M. H. A. Darwish. 2013. The effect of chinese propolis supplementation on ross broiler performance and carcass characteristics. J. Adv. Vet. Res. 3:154-160.

Mahmoud, U. T., O. A. Amen, T. J. Applegate, \& H. W. Cheng. 2017. Brazilian propolis effects on growth, productivity performance, gut characteristics and physiological changes in broiler chickens. Int. J. Poult. Sci. 16:169-179. https:// doi.org/10.3923/ijps.2017.169.179

Miles, R. D., G. D. Butcher, P. R. Henry, \& R. C. Littell. 2006. Effect of antibiotic growth promoters on broiler performance, intestinal growth parameters, and quantitative morphology. Poult. Sci. 85:476-485. https://doi.org/10.1093/ ps/85.3.476

Mountzouris, K. C., P. Tsitrsikos, I. Palamidi, A. Arvaniti, M. Mohnl, G. Schatzmayr, \& K. Fegeros. 2010. Effects of probiotic inclusion levels in broiler nutrition on growth performance, nutrient digestibility, plasma immunoglobulins, and cecal microflora composition. Poult. Sci. 89:58-67 http://dx.doi.org/10.3382/ps.2009-00308

Nasution, A. Y., P. Adi, \& P. A. Santosa. 2015. Effect of propolis extract on levels of SGOT (serum glutamic oxaloacetic transaminase) and SGPT (serum glutamic pyruvic transaminase) in white rats (Rattus norvegicus) wistar strain on a high-fat diet. Majalah Kesehatan FKUB 2:120-126.

Noy, Y. \& D. Sklan. 1999. Energy utilization in newly hatched chicks. Poult. Sci. 78:1750-1756. https://doi.org/10.1093/ ps/78.12.1750

Oakley, B. B. \& M. H. Kogut. 2016. Spatial and temporal changes in the broiler chicken cecal and fecal microbiomes and correlations of bacterial taxa with cytokine gene expression. Front. Vet. Sci. 3:11. https://doi.org/10.3389/ fvets.2016.00011 
Pimenta, H. C., I. M. ari. P. Violante, C. R. alp. de Musis, Á. H. Borges, \& A. M. ari. F. Aranha. 2015. In vitro effectiveness of Brazilian brown propolis against Enterococcus faecalis. Braz. Oral Res. 29:1-6. https://doi.org/10.1590/18073107BOR-2015.vol29.0058

Pinheiro, J., D. Bates, S. DebRoy, D. Sarkar, Eispack, S. Heisterkamp, \& B. V. Willigen. 2020. "Package 'Nlme' March. R Core Team. 1-335.

Prakatur, I., M. Miskulin, M. Pavic, K. Marjanovic, V. Blazicevic, I. Miskulin, \& M. Domacinovic. 2019. Intestinal morphology in broiler chickens supplemented with propolis and bee pollen. Animals 9:301. https://doi. org/10.3390/ani9060301

Przybyłek, I. \& T. M. Karpiński. 2019. Antibacterial properties of propolis. Molecules 24:11-13. https://doi.org/10.3390/ molecules 24112047

R Core Team. 2020. R: A Language and Environment for Statistical Computing. R Core Team.

Rabie, A. H., A. M. El-Kaiaty, M. S. Hassan, \& F. R. Stino. 2018. Influence of some honey bee products and a growth promoter supplementation on productive and physiological performance of broiler chickens. Egypt. Poult. Sci. J. 38:513-531.

Romier, B., Y. J. Schneider, Y. Larondelle, \& A. During. 2009. Dietary polyphenols can modulate the intestinal inflammatory response. Nutr. Rev. 67:363-378. https://doi. org/10.1111/j.1753-4887.2009.00210.x

Sahin, H. A. \& E. Ozturk. 2018. Effects of raw propolis or water and ethanol extracts of propolis on performance, immune system, and some blood parameters of broiler breeders. Rev. Bras. Zootec. 47:e20170161. https://doi.org/10.1590/ rbz4720170161

Sauvant, D., P. Schmidely, \& J. J. Daudin. 2008. Meta-analyses of experimental data in animal nutrition*. Animal. 2:12031214. https://doi.org/10.1017/S1751731108002280

Seven, P. T. \& I. Seven. 2008. Effect of dietary turkish propolis as alternative to antibiotic on performance and digestibility in broilers exposed to heat stress. J. Appl. Anim. Res. 34:193-196. https://doi.org/10.1080/09712119.2008.9706970

Seven, I., T. Aksu, \& P. Tatli-Seven. 2010. The effects of propolis on biochemical parameters and activity of antioxidant enzymes in broilers exposed to lead-induced oxidative stress. Asian-Australas. J. Anim. Sci. 23:1482-1489. https:// doi.org/10.5713/ajas.2010.10009

Seven, I., T. Aksu, \& P. Tatli-Seven. 2012. The effects of propolis and vitamin $C$ supplemented feed on performance, nutrient utilization and carcass characteristics in broilers exposed to lead. Livest. Sci. 148:10-15. https://doi. org/10.1016/j.livsci.2012.05.001

Sforcin, J. M. 2016. Biological properties and therapeutic applications of propolis. Phytother. Res. 30:894-905. https://doi. org/10.1002/ptr.5605

Shaddel-Tili, A., B. Eshratkhah, H. Kouzehgari, \& M. GhasemiSadabadi. 2017. The effect of different levels of propolis in diets on performance, gastrointestinal morphology and some blood parameters in broiler chickens. Bulg. J. Vet. Med. 20:215-224. https://doi.org/10.15547/bjvm.986
Shalmany, K. S. \& M. Shivazad. 2006. The effect of diet propolis supplementation on Ross broiler chicks performance. Int. J. Poult. Sci. 5:84-88. https://doi.org/10.3923/ijps.2006.84.88

Silva, R. P. D., B. A. S. Machado, G. De Abreu Barreto, S. S. Costa, L. N. Andrade, R. G. Amaral, A. A. Carvalho, F.F. Padilha, J. D. V. Barbosa, \& M. A. Umsza-Guez. 2017. Antioxidant, antimicrobial, antiparasitic, and cytotoxic properties of various Brazilian propolis extracts. PLoS One 12:1-18. https://doi.org/10.1371/journal.pone.0173397

St-Pierre, N. R. 2001. Invited review: Integrating quantitative findings from multiple studies using mixed model methodology. J. Dairy Sci. 84:741-55. https://doi.org/10.3168/jds. S0022-0302(01)74530-4

Taheri, H. R., H. R. Rahmani, \& J. Pourreza. 2005. Humoral immunity of broilers is affected by oil extracted propolis (OEP) in the diet. Int. J. Poult. Sci. 4:414-417. https://doi. org/10.3923/ijps.2005.414.417

Tatli Seven, P., I. Seven, M. Yilmaz, \& Ü.G. Şimşek. 2008. The effects of Turkish propolis on growth and carcass characteristics in broilers under heat stress. Anim. Feed Sci. Technol. 146:137-148. https://doi.org/10.1016/j. anifeedsci.2007.11.003

Tayeb, I. T. \& B. F. Sulaiman. 2014. Effect of propolis supplementation on productive performance in local quail. Iran. J. Appl. Anim. Sci. 4:621-627.

Tekeli, A., H. Kutlu, L. Celik, \& F. Doran. 2010. Determination of the effects of $Z$. officinale and propolis extracts on intestinal microbiology and histological characteristics in broilers. Int. J. Poult. Sci. 9:898-906. https://doi.org/10.3923/ ijps.2010.898.906

Temizer, I. K., A. Güder, \& O. G. Çelemli. 2017. Botanical origin and antioxidant activities of propolis from the IranoTuranian region. Istanbul J. Pharm. 47:107-111.

Torki, M., J. Soltani, \& H. Mohammadi. 2015. Effects of adding ethanol extract of propolis and cumin essential oil to diet on the performance, blood parameters, immune response and carcass traits of broiler chicks. Iran. J. Appl. Anim. Sci. 5:911-918

Wang, B. J., Y. H. Lien, \& Z. R. Yu. 2004. Supercritical fluid extractive fractionation-study of the antioxidant activities of propolis. Food Chemist. 86:237-243. https://doi. org/10.1016/j.foodchem.2003.09.031

Wang, J., S. Li, Q. Wang, B. Xin, \& H. Wang. 2007. Trophic effect of bee pollen on small intestine in broiler chickens. J. Med. Food. 10:276-280. https://doi.org/10.1089/jmf.2006.215

Wang, S., Q. Ye., Q. Zeng, \& S. Qiao. 2019. Functions of macrophages in the maintenance of intestinal homeostasis. J. Immunol. Res. 2019:1-9. https://doi. org/10.1155/2019/1512969

Zafarnejad, K., N. Afzali, \& M. Rajabzadeh. 2017. Effect of bee glue on growth performance and immune response of broiler chickens. J. Appl. Anim. Res. 45:280-284. https:// doi.org/10.1080/09712119.2016.1174130

Ziaran, H. R., H. R. Rahmani, \& J. Pourreza. 2005. Effect of dietary oil extract of propolis on immune response and broiler performance. Pak. J. Biol. Sci. 8:1485-1490. https:// doi.org/10.3923/pjbs.2005.1485.1490 